\title{
Analysis of the IDDM Candidate Gene Prss16 in NOD and NON Mice
}

\author{
SAIJAI CHEUNSUK ${ }^{\mathrm{a}}$, TOM HSU ${ }^{\mathrm{b}}$, M. ERIC GERSHWIN ${ }^{\mathrm{b}}$ and CHRISTOPHER L. BOWLUS ${ }^{\mathrm{a}, *}$
}

${ }^{\mathrm{a}}$ Division of Gastroenterology, Department of Internal Medicine, University of California Davis, Davis, CA 95616, USA; ${ }^{\mathrm{b}}$ Division of Rheumatology, Allergy and Clinical Immunology, Department of Internal Medicine, University of California Davis, Davis, CA 95616, USA

\begin{abstract}
The thymus-specific serine protease Prss16 is highly expressed by the epithelial cells in the thymic cortex. It has been suggested to play an important role in the positive selection of $\mathrm{T}$ cells through the antigen presention pathway of the cortical antigen presenting cells. Recently, the gene ecoding Prss 16 has been linked to insulin dependent diabetes mellitus (IDDM) susceptibility independent of HLA-DR3 suggesting the Prss16 may be involved in the development of autoimmune disease. Due to the similarities of the gene structure and expression pattern between the human and mouse genes, we compared Prss16 between non-obese diabetic (NOD) and non-obese non-diabetic (NON) mice. Analysis of the Prss 16 coding region failed to identify any differences in sequence. Northern analysis and semi-quantitative reverse transcriptase polymerase chain reaction showed that the mRNA was equal in size and abundance in the two strains. In situ hybridization showed similar patterns of staining. Therefore, our data suggests that there is no significant different in the gene structure, transcription level, and expression pattern of Prss16 gene between NOD and NON mice.
\end{abstract}

Keywords: Thymus; Prss 16; Serine protease; Polymorphisms; NOD; Diabetes

Type 1 or insulin-dependent diabetes mellitus (IDDM) is a polygenic autoimmune disease caused by $\mathrm{T}$ cell-mediated destruction of insulin-producing pancreatic $\beta$ cells (Birk and Cohen, 1993; Vyse and Todd, 1996). IDDM susceptibility is most tightly associated with genes linked to the HLA region of the Major Histocompatability Complex (MHC) on human chromosome 6p21. The strongest associations reside within the HLA-DRB1, HLA$D Q A 1$, and $H L A-D Q B 1$ (class II) regions (Todd et al., 1987; Nepom, 1995). However, variants in this region do not fully explain the association between the MHC and IDDM (Robinson et al., 1993; Lie et al., 1999a). Using transmission disequilibrium testing, Lie et al. have shown evidence for an IDDM susceptibility locus independent of MHC class II located telomeric of the MHC region near the D6S2223. The strongest candidate gene for this susceptibility locus is Prss16, also referred to as thymus specific serine protease (Bowlus et al., 1999).

Prss16 encodes a protein with homology to prolylcarboxypeptidase (PCP) and is specifically expressed by cortical epithelial cells in the thymus. The pattern of expression around the thymic capsule and vessels is similar to that reported for cathepsin L, a protease involved in antigen presentation during the positive selection of T cells (Nakagawa et al., 1998). Similarly, Prss16 is believed to function in the positive selection of
T cells. Defects in positive selection have been implicated in the development of autoimmunity and IDDM, in particular (Luhder et al., 1998).

The purpose of this study was to evaluate Prss16 as a diabetes susceptibility locus in the non-obese diabetic (NOD) mouse by comparison to the non-obese non diabetic (NON) mouse. Mutations that might effect the coding region, mRNA size and expression were screened for by direct sequencing, Northern hybridization, semiquantitative real-time PCR, and in situ hybridization.

\section{MATERIALS AND METHODS}

\section{DNA Sequencing}

NON and NOD mice genomic DNA was purchased from the Jackson Laboratory (Maine, USA). Seven pairs of primers were designed using Primer Express software (Applied Biosystems, Foster City, CA) for amplification and sequencing of all 12 exons in both strains of mice (Table I). PCR reactions were performed under the following conditions: $4 \mathrm{ng} / \mu \mathrm{l}$ template DNA, $1 \mathrm{pmol} / \mu \mathrm{l}$ each primer, $1 \mathrm{mM}$ dNTPs, $1.5 \mathrm{mM} \mathrm{MgCl}_{2}, 1 \mathrm{X}$ PCR Buffer, $0.02 \mathrm{U} / \mu \mathrm{l}$ Taq polymerase in a final volume of $50 \mu$ l. Cycling conditions were: $94^{\circ} \mathrm{C}$ for $3 \mathrm{~min}, 35$ cycles $\mathrm{X}\left(94^{\circ} \mathrm{C}\right.$ for $45 \mathrm{~s}, 56^{\circ} \mathrm{C}$ for $45 \mathrm{~s}$, and $72^{\circ} \mathrm{C}$ for $\left.1 \mathrm{~min}\right)$,

\footnotetext{
*Corresponding author. Division of Gastroenterology, UC Davis Medical Center, 4635 2nd Avenue, Sacramento, CA 95817, USA. Tel.: + 1-916-734-0857. Fax: + 1-916-456-7727. E-mail: clbowlus@ucdavis.edu
} 
TABLE I Primers used for amplification and sequencing of Prss16 in NOD and NON mice

\begin{tabular}{lll}
\hline Exon(s) & \multicolumn{1}{c}{ Forward primer } & \multicolumn{1}{c}{ Reverse primer } \\
\hline 1,2 & EX 1/2.F (GGACAAAAGAGCAGAGTGCC) & EX1/2.R (AGAAAGCAAGGAACTGGGGT) \\
3,4 & EX 3/4.F (GGGGGAAATCTTGGAGAAAA) & EX 3/4.R (CACAGCGGTGGATACTAACAGA) \\
$5-7$ & EX 5/6/7.F (GTTACCGGAAGGAACCTTGG) & EX5/6/7.R (CGCCTTCCTCCACACTCTAC) \\
8 & EX 8.F (GAGGACAGGGAGTGAGGTTG) & EX 8.R (TTTGGCCCATTAGTCTCTGG) \\
9 & EX 9.F (GAGAAGAGGGAACATGCAGC) & EX 9.R (TTCGGTTTGGGAGTTAGGTG) \\
10,11 & EX 10/11.F (GAGAAGAGCAGGAGGCTGTC) & EX 10/11.R (GGAGTCAGAACTCAGCACCA) \\
12 & EX 12.F (GGTGCTGAGTTCTGACTCCA) & EX12.R (GCCAGTCAGGATTGAGGAGA) \\
\hline
\end{tabular}

$72^{\circ} \mathrm{C}$ for $4 \mathrm{~min}$. All PCR products were analyzed on a $1 \%$ agarose gel and sequenced with the same primers on an ABI 377 Sequencer using Big Dye Terminator Cycle Sequencing kit (Applied Biosystems, Foster City, CA). Sequences were aligned using Sequencher software (Genecodes, Ann Arbor, MI).

\section{Total RNA Isolation, Probe Labeling, and Northern Blot Analysis}

Six-week-old male C57BL/6, NOD/LtJ and NON/LtJ mice were purchased from the Jackson Laboratory (Maine, USA). Total RNA was prepared from the mouse thymi using TriZol ${ }^{\circledR}$ Reagent (Life Technologies, Rockville, MD. USA) according to the manufacturer's instructions. Total RNA $(10 \mu \mathrm{g})$ was separated on $0.8 \%$ formaldehyde agarose gel and transferred onto Hybond-N+ nylon transfer membrane (Amersham Pharmacia Biotech, Piscataway, NJ, USA). A mouse cDNA clone (Genbank Accession AI587874) was radiolabeled and hybridized as previously described. After two washes each in $2 \times \mathrm{SSC}, 0.1 \%$ SDS for $20 \mathrm{~min}$ at room temperature and $0.2 \times \mathrm{SSC}, 0.1 \% \mathrm{SDS}$ for $20 \mathrm{~min}$ at $65^{\circ} \mathrm{C}$, the membrane was exposed to the phosphor screen for $72 \mathrm{~h}$ at room temperature, then analyzed using the PhosphorImager (Molecular Dynamics, Sunnyvale, CA, USA).

\section{Thymic Stromal Cell Population Enrichment and Real Time RT-PCR}

Stromal cells were isolated from the thymi of 3 weeksold male NOD $(n=4)$ and NON $(n=4)$ mice as previously described (French et al., 1997). Briefly, fresh thymus was cut into small pieces, suspended in RPMI 1640 (Life Technologies, Grand Island, NY, USA), and homogenized in a loosely fitting glass homogenizer. The cell suspension was filtered through a $100-\mu \mathrm{m}$ pore cell strainer (FALCON) and left to sediment at $4^{\circ} \mathrm{C}$ for $10 \mathrm{~min}$. The supernatant was separated from the sediment. The material retained by the strainer and the sediment were resuspended in cold $\left(4^{\circ} \mathrm{C}\right) \mathrm{PBS}$ and left to sediment at $4^{\circ} \mathrm{C}$ for $10 \mathrm{~min}$, and the supernatant was separated from the sediment and the procedure was repeated three times. The final sediment was briefly pelleted at $800 \mathrm{~g}$ and RNA was extracted using TriZol ${ }^{\circledR}$ reagent as described above.
Semi-quantitative real time PCR was performed on an ABI 7700 Sequence Detector using SYBR ${ }^{\circledR}$ Green Assays (PE Biosystems, Foster City, CA, USA.). Briefly, $500 \mu \mathrm{g}$ of stromal RNA was reverse transcribed in a $20 \mu \mathrm{l}$ reaction using SuperScript Reverse Transcriptase (Life Technologies) with $2.5 \mathrm{mM}$ random hexamer primer (Life Technologies) according to the manufacturer's instructions. $5 \mu \mathrm{l}$ of 1:50 dilution of cDNA reaction was used for template with primers TQ 295F (CAGCCACTGGATCCCTTCA) and TQ 262R (TGATCATTCACCCAGTA$\mathrm{CCGC}$ ) in a $50 \mu \mathrm{l}$ reaction according to the manufacturer's recommendations. Cycling consisted of: $1 \times 50^{\circ} \mathrm{C}$ for $2 \mathrm{~min}, 1 \times 95^{\circ} \mathrm{C}$ for $10 \mathrm{~min}, 40 \times\left(95^{\circ} \mathrm{C}\right.$ for $15 \mathrm{~s}, 60^{\circ} \mathrm{C}$ for $1 \mathrm{~min})$. Similarly, the $18 \mathrm{~S}$ ribosomal RNA was amplified with primers 18S.F (CTACCACATCCAAGGAAGGCA) and 18S.R (CAGACTTGCCCTCCAATGGA). All samples were performed in triplicate. PCR products were separated on a $2 \%$ agarose gel to confirm specific amplification. Quantitation was performed using Sequence Detector V1.7. A standard cDNA derived from a C57BL6 mouse thymus was used as a calibrator in each assay.

\section{In Situ Hybridization}

Mouse thymi from the NOD and NON mice were sectioned at $8 \mu \mathrm{m}$ and fixed in $4 \%$ paraformaldehyde. Sense and antisense cRNA probes were generated from the same cDNA clone used for Northern hybridization with incorporation of digoxigenin-UTP (Roche Molecular Biochemicals, Indianopolis, IN, USA). Probes were hybridized overnight at $58^{\circ} \mathrm{C}$ to thymic sections and washed. Following incubation with alkaline phosphataseconjugated anti-digoxigenin antibody, slides were incubated in BCIP/NBT at room temperature for $36 \mathrm{~h}$. The section were counterstained with Nuclear Fast Red (Vector Laboratories, Burlingame, CA, USA) and analyzed by light microscopy.

\section{RESULTS}

\section{Genomic Structure}

To determine the genomic structure of the mouse Prss 16 gene in both NOD and NON mice, genomic DNA was sequenced with seven different pairs of primers. No differences in sequence were identified between NOD and NON. 
(a)

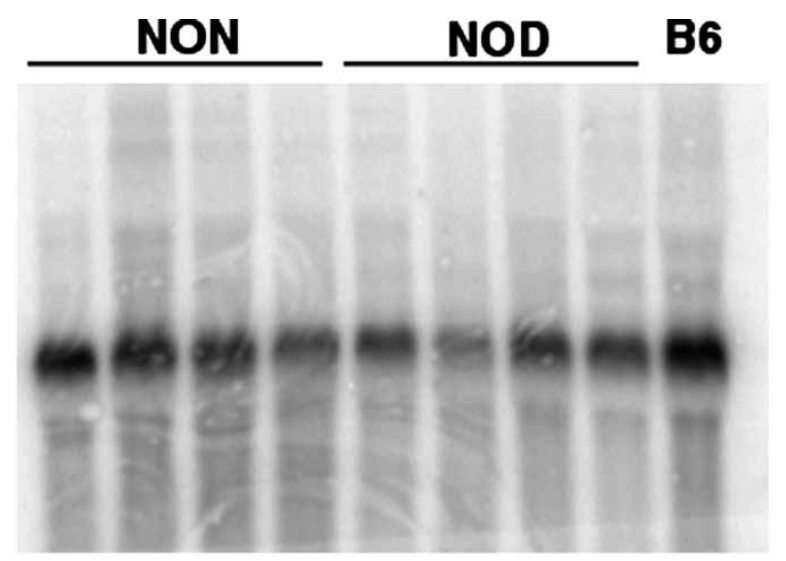

(b)

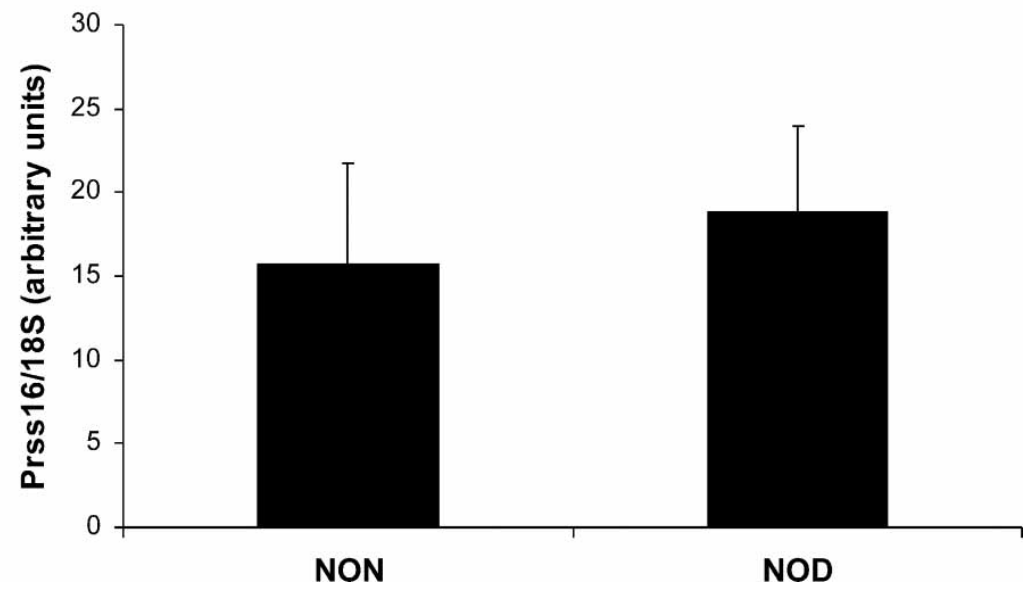

FIGURE 1 (a) Northern hybridization of Prss 16 probe to total thymus RNA from C57BL/6, NOD $(n=4)$ and NON $(n=4)$ mice. (b) Prss 16 mRNA relative to $18 \mathrm{~S}$ ribosomal RNA in thymic stromal cells from the thymi of three weeks old male NOD $(n=4)$ and NON $(n=4)$ mice. Shown is the average and SEM for Prss16 mRNA relative to $18 \mathrm{~S}$ rRNA.

\section{Prss16 Expression in NOD and NON Mice}

Since NOD mice have abnormal thymic structure and develop the autoimmune phenotype, we investigated the thymic expression of Prss16 in NOD and NON mice. Northern blots of NOD and NON thymus RNA were used to screen for Prss16 mRNA level and size (Fig. 1a). No difference in size or band intensity could be detected. We also performed semi-quantitative PCR on thymic stromal cells to further investigate differences in Prss 16 mRNA (Fig. 1b). When normalized to $18 \mathrm{~S}$ rRNA, no difference in the relative amount of Prss16 in the thymic stromal cells from NOD and NON mice could be detected $(p>0.70)$.

We have previously shown by in situ hybridization that Prss16 is much more prevalent in C57BL6 and BALB/C than NOD thymus (Cheunsuk et al., 2002). However, comparison of NOD to NON thymus failed to reveal any notable difference in the pattern or density of Prss16 staining (Fig. 2).

\section{DISCUSSION}

Identification of genetic variants that confer susceptibility to or protection from IDDM is important to identify high-risk individuals and potential targets for preventive therapies. Several susceptibility loci have been identified including the MHC class II, the INS VNTR and most recently CTLA4 (Eaves et al., 1999; Ueda et al., 2003). Similar influences of these loci have also been reported in NOD mice supporting its role as a model of IDDM.

In total, more than 20 non-MHC linked genes have been suggested to influence diabetes susceptibility with the MHC contributing the greatest influence (Griffiths et al., 1999; Grattan et al., 2002). Most of this effect has been attributed to the unusual sequence of the HLA-DQ allele in humans and $\mathrm{H} 2^{g 7}$ allele in NOD mice which both encode non-aspartic acid residues at position 57 of the $\beta$ chain. However, other
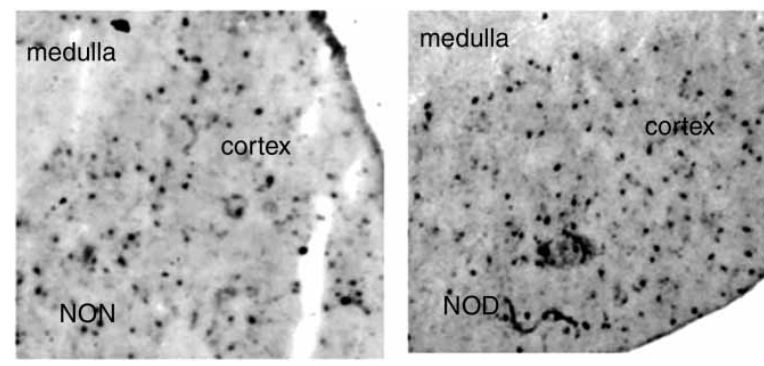

FIGURE 2 In situ hybridization of Prss16 to thymi from NOD and NON mice. 
genetic influences linked to the MHC have been suggested by several studies. Dissecting out the precise locus has been difficult due to the strong linkage disequilibrium in the region. However, using transmission disequilibrium tests, a clear association has been established in the region telomeric of the MHC class I region on chromosome (Lie et al., 1999). Notably, the rate of transmission of the D6S2223 allele 3 was 0.2 in probands compared to the expected 0.5 . In addition, this same allele is associated with susceptibility to celiac disease (Lie et al., 1999b).

Several polymorphisms in Prss 16 have recently been identified including a missense mutation and a 15 base pair deletion (7548_7563del) predicted to result in a loss of 5 amino acids (Lie et al., 2002). Interestingly, the 7548 7563del has an allele frequency of 0.17 and is in linkage disequilibrium with the DQA $1 * 05-\mathrm{DQB} 1 * 02$ haplotype. The potential association between this and other polymorphisms with IDDM is currently under investigation.

In mouse, the orthologue of Prss 16 is highly conserved with expression similarly restricted to thymic cortical epithelial cells (Cheunsuk et al., 2002). In addition, Prss16 is expressed at lower levels in autoimmune prone mice such as NOD and New Zealand Black (NZB) mice compared to C57BL6 and BALB/C mice. However, Prss16 is not syntenic to the MHC on mouse chromosome 17. Rather, it is encoded in the comparative region centromeric of the satin $(\mathrm{sa})$ locus on mouse chromosome 13. Idd 14 is a diabetes susceptibility locus that has been mapped to chromosome 13 linked to D13Mit61 (McAleer et al., 1995). This locus was identified by an outcross of NOD with congenic NON.H2 $2^{\mathrm{g} 7}$ followed by an $\mathrm{F} 1$ intercross. In the F2 generation, susceptibility was associated with increased NOD homozygosity and decreased NON homozygosity at D13Mit61.

For these reasons, we investigated Prss 16 as a possible susceptibility gene for the development of diabetes in NOD mice. Analysis of Prss 16 gene of NOD and NON mice demonstrated no mutation in the coding sequence of the NOD mice compare to that of the NON mice. Previously, we have shown by in situ hybridization that Prss16 expression in NOD mice is lower compared to C57BL6 and Balb/c mice. In addition, lower expression is also noted in NZB mice which are prone to autoimmune disease as well. However, we found no difference by in situ hybridization between NOD and NON mice. In all strains gene expression is specific to cortical epithelial cells. Furthermore, Northern analysis and the semiquantitative PCR did not demonstrate any significant different in transcript size or abundance between the strains.

In conclusion, we have evaluated Prss 16 as a candidate gene for diabetes susceptibility in NOD mice. We were unable to detect any differences in the coding sequence, transcript size or transcript abundance. Although we cannot conclusively rule out Prss16 as the Idd14 diabetes susceptibility gene in the NOD mouse, our results make it highly unlikely. Interestingly, more closely linked with D13Mit61 is cathepsin L which when deleted in mice has been shown to result in abnormal selection of CD4+ T cells and development of natural killer $\mathrm{T}$ cells (Honey et al., 2002). Further investigation of cathepsin $\mathrm{L}$ as the Idd 14 susceptibility gene is warranted. It is important to note that our results do not exclude Prss16 as a susceptibility gene in human IDDM.

\section{References}

Birk, O.S. and Cohen, I.R. (1993) "T-cell autoimmunity in type 1 diabetes mellitus", Curr. Opin. Immunol. 5, 903-909.

Bowlus, C.L., Ahn, J., Chu, T. and Gruen, J.R. (1999) "Cloning of a novel MHC-encoded serine peptidase highly expressed by cortical epithelial cells of the thymus", Cell Immunol. 196, 80-86.

Cheunsuk, S., Sparks, R., Noveroske, T., Hsu, Justice, M.J., Gershwin, M.E., Gruen, J.R. and Bowlus, C.L. (2002) "Expression, genomic structure and mapping of the thymus specific protease prss16: a candidate gene for insulin dependent diabetes mellitus susceptibility", J. Autoimmun. 18, 311-316.

Eaves, I.A., Bennett, S.T., Forster, P., Ferber, K.M., Ehrmann, D., Wilson, A.J., Bhattacharyya, S., et al. (1999) "Transmission ratio distortion at the INS-IGF2 VNTR”, Nat. Genet. 22, 324-325.

French, L.E., Wilson, A., Hahne, M., Viard, I., Tschopp, J. and MacDonald, H.R. (1997) "Fas ligand expression is restricted to nonlymphoid thymic components in situ", J. Immunol. 159, 2196-2202.

Grattan, M., Mi, Q.S., Meagher, C. and Delovitch, T.L. (2002) "Congenic mapping of the diabetogenic locus Idd4 to a 5.2-cM region of chromosome 11 in NOD mice: identification of two potential candidate subloci”, Diabetes 51, 215-223.

Griffiths, M.M., Encinas, J.A., Remmers, E.F., Kuchroo, V.K. and Wilder, R.L. (1999) "Mapping autoimmunity genes", Curr. Opin. Immunol. 11, 689-700.

Honey, K., Benlagha, K., Beers, C., Forbush, K., Teyton, L., Kleijmeer, M.J., Rudensky, A.Y. and Bendelac, A. (2002) "Thymocyte expression of cathepsin L is essential for NKT cell development", Nat. Immunol. 3, 1069-1074.

Lie, B.A., Todd, J.A., Pociot, F., Nerup, J., Akselson, H.E., Ronningen, K.S. Joner, G., Dahl-Jorgensen, K., et al. (1999) “The predisposition to type 1 diabetes linked to the human leukocyte antigen complex includes at least one non-class II gene", Am. J. Hum. Genet. 64, 793-800.

Lie, B.A., Sollid, L.M., Ascher, H., Ek, J., Akselsen, H.E., Ronningen, K.S., Thorsby, E. and Undlien, D.E. (1999) "A gene telomeric of the HLA class I region is involved in predisposition to both type 1 diabetes and coeliac disease", Tissue Antigens 54, 162-168.

Lie, B.A., Akselsen, H.E., Bowlus, C.L., Gruen, J.R., Thorsby, E. and Undlien, D.E. (2002) "Polymorphisms in the gene encoding thymusspecific serine protease in the extended HLA complex: a potential candidate gene for autoimmune and HLA-associated diseases", Genes Immun. 3, 306-312.

Luhder, F., Katz, J., Benoist, C. and Mathis, D. (1998) "Major histocompatibility complex class II molecules can protect from diabetes by positively selecting T cells with additional specificities", J. Exp. Med. 187, 379-387.

McAleer, M.A., Reifsnyder, P., Palmer, S.M., Prochazka, M., Love, J.M., Copeman, J.B., Powell, E.E., et al. (1995) "Crosses of NOD mice with the related NON strain. A polygenic model for IDDM", Diabetes 44, 1186-1195.

Nakagawa, T., Roth, W., Wong, P., Nelson, A., Farr, A., Deussing, J., Villadangos, J.A., et al. (1998) "Cathepsin L: critical role in Ii degradation and CD4 T cell selection in the thymus", Science 280, 450-453.

Nepom, G.T. (1995) "Class II antigens and disease susceptibility", Annu. Rev. Med. 46, 17-25.

Robinson, W.P., Barbosa, J., Rich, S.S. and Thomson, G. (1993) "Homozygous parent affected sib pair method for detecting disease predisposing variants: application to insulin dependent diabetes mellitus", Genet. Epidemiol. 10, 273-288.

Todd, J.A., Bell, J.I. and McDevitt, H.O. (1987) "HLA-DQ beta gene contributes to susceptibility and resistance to insulin-dependent diabetes mellitus", Nature 329, 599-604.

Ueda, H., Howson, J.M., Esposito, L., Heward, J., Snook, H., Chamberlain, G., Rainbow, D.B., et al. (2003) "Association of the T-cell regulatory gene CTLA4 with susceptibility to autoimmune disease", Nature 30, 30.

Vyse, T.J. and Todd, J.A. (1996) "Genetic analysis of autoimmune disease", Cell 85, 311-318. 


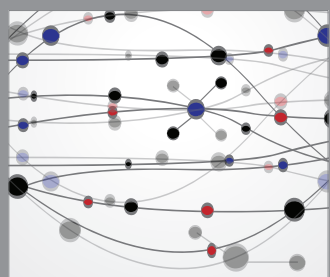

The Scientific World Journal
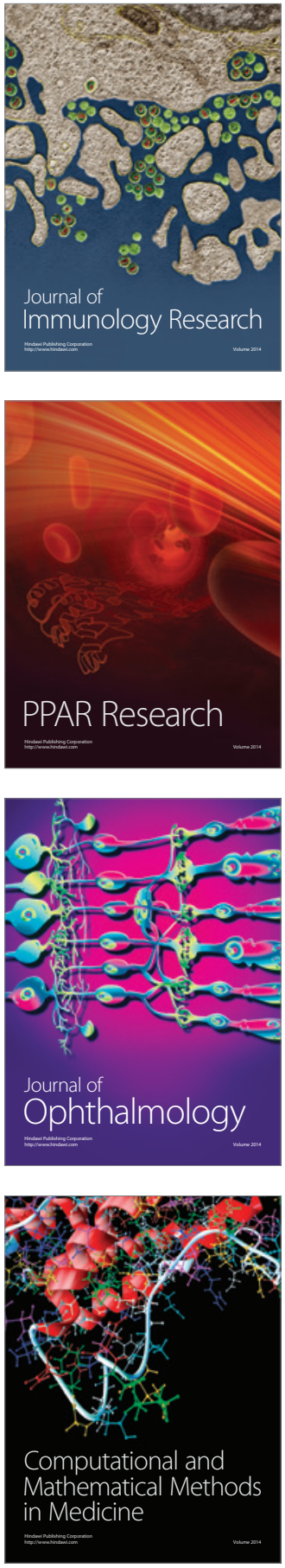

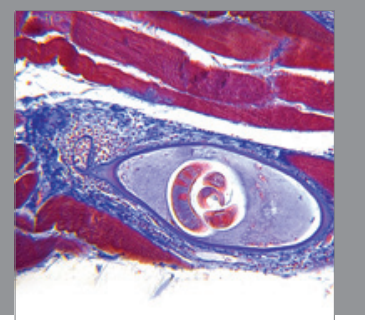

Gastroenterology

Research and Practice
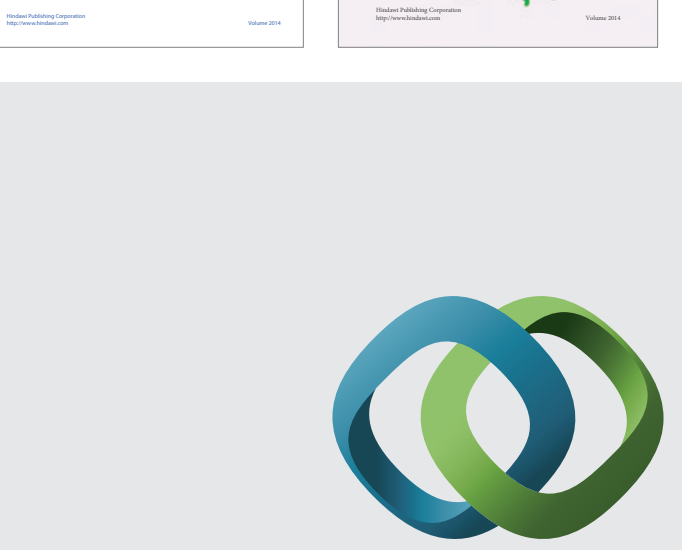

\section{Hindawi}

Submit your manuscripts at

http://www.hindawi.com
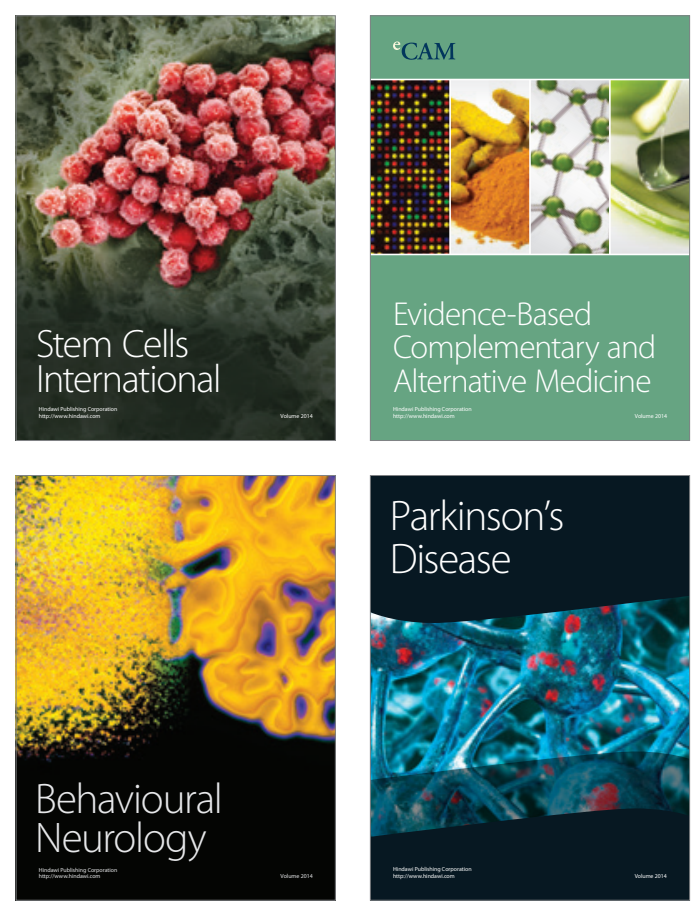

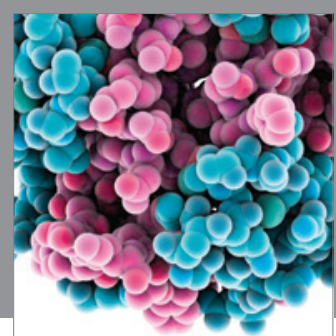

Journal of
Diabetes Research

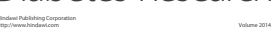

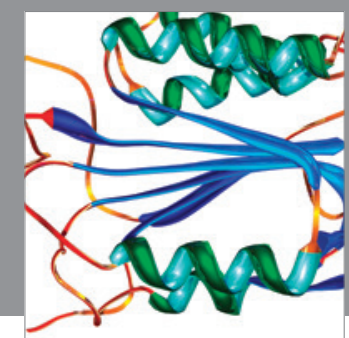

Disease Markers
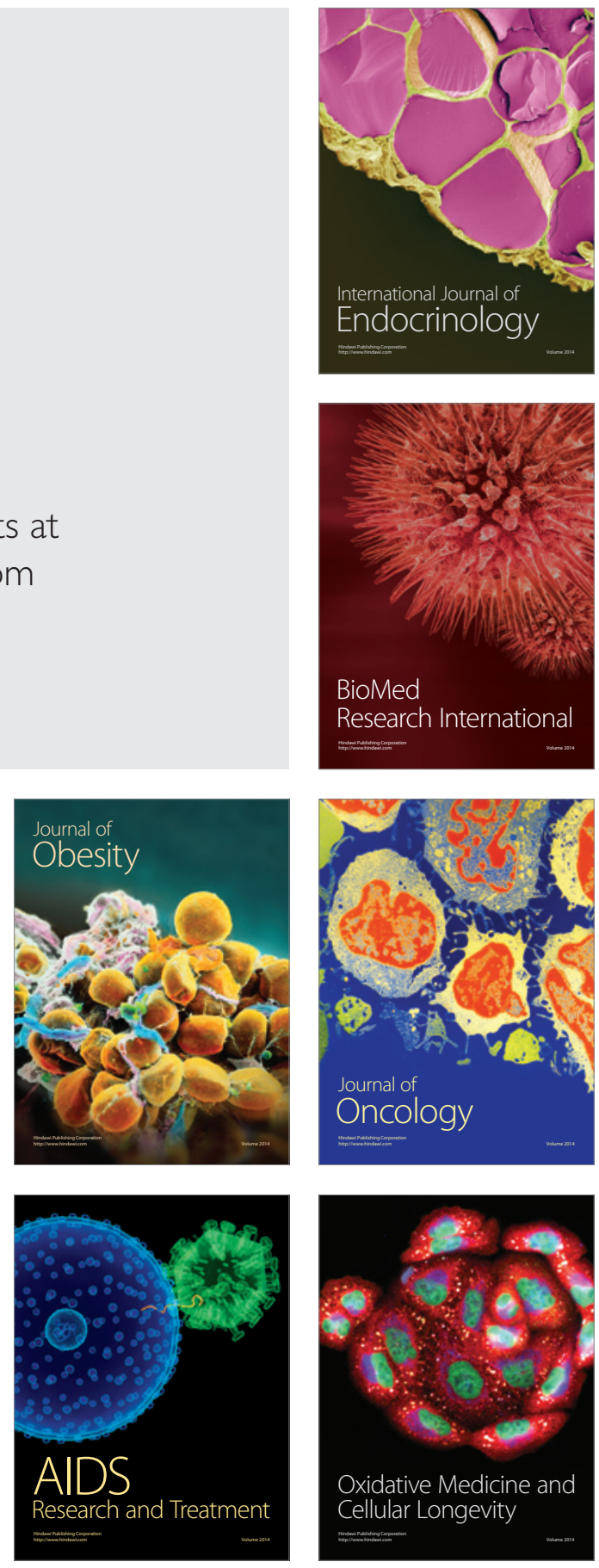